\title{
A New Occurrence of Archaeoscyphia Pulchra (Bassler) from the Ordovician of Western Canada
}

\author{
J. Keith Rigby \\ Brigham Young University - Provo
}

Godfrey S. Nowlan

Geological Survey of Canada

Peter A. Rowlands

Follow this and additional works at: https://scholarsarchive.byu.edu/facpub

Part of the Geology Commons

\section{Original Publication Citation}

Rigby, J. Keith, Godfrey S. Nowlan, and Peter A. Rowlands. "A New Occurrence of Archaeoscyphia Pulchra (Bassler) from the Ordovician of Western Canada." Canadian Journal of Earth Sciences $=$ Revue Canadienne des Sciences de la Terre 39.7 (2002): 1065-9.

\section{BYU ScholarsArchive Citation}

Rigby, J. Keith; Nowlan, Godfrey S.; and Rowlands, Peter A., "A New Occurrence of Archaeoscyphia Pulchra (Bassler) from the Ordovician of Western Canada" (2002). Faculty Publications. 1453.

https://scholarsarchive.byu.edu/facpub/1453

This Other is brought to you for free and open access by BYU ScholarsArchive. It has been accepted for inclusion in Faculty Publications by an authorized administrator of BYU ScholarsArchive. For more information, please contact ellen_amatangelo@byu.edu. 


\title{
A new occurrence of Archaeoscyphia pulchra (Bassler) from the Ordovician of western Canada ${ }^{1}$
}

\author{
J. Keith Rigby, Godfrey S. Nowlan, and Peter A. Rowlands
}

\begin{abstract}
A few specimens of the ornate anthaspidellid demosponge, Archaeoscyphia pulchra (Bassler), have been collected from the Lower Ordovician Outram Formation or Skoki Formation, from a saddle at the head of South Rice Brook in northeastern British Columbia. This is the first report of the flanged-appearing annulate, steeply obconical sponge in western Canada, although it has been reported from the Mingan Islands of Quebec and was initially described from Nevada, in the western United States. The taxon has also been reported as other species of Archaeoscyphia from Ordovician rocks of Missouri and from the San Juan region of Argentina.
\end{abstract}

Résumé : Quelques spécimens de Démosponges anthaspidellides ornées, Archaeoscyphia pulchra (Bassler) ont été recueillis dans la Formation d'Outram ou de Skoki (Ordovicien inférieur); ils proviennent d'un col à la tête du ruisseau South Rice dans le nord-est de la Colombie-Britannique. Ce rapport est le premier sur l'éponge étroitement obconique, annelée et à apparence de collerette dans l'ouest du Canada, bien qu'elle ait été rapportée aux îles Mingan, au Québec, et que la description initiale provienne du Nevada, dans l'ouest des États-Unis. Le taxon a aussi été rapporté en tant que d'autres espèces d'Archaeoscyphia trouvées dans des roches ordoviciennes du Missouri et de la région de San Juan, en Argentine.

[Traduit par la Rédaction]

\section{Introduction}

A nearly complete specimen and an additional fragment of this ornate sponge have been recovered from Lower Ordovician rocks, most probably of the upper part of the Outram Formation or the lower part of the Skoki Formation, from near the Columbia Icefields in the Main Ranges of the Rocky Mountains of eastern British Columbia. The relatively rare species was initially described from Lower Ordovician rocks of the Toquima Range from central Nevada by Bassler (1941), and nearby areas by Johns (1994). It has also been reported from the Mingan Islands of Quebec by Rigby and Desrochers (1995), and possibly from the Ordovician of the Ozark Uplift of Missouri, where Cullison (1944) described the similar Archaeoscyphia annulata, which Johns (1994) placed in synonymy with Archaeoscyphia pulchra.

The exceptionally well-preserved and silicified western Canadian specimens were collected by one of us (PR) while climbing with the Alpine Club of Canada. The sponges came from Geological Survey of Canada (GSC) locality C-403152, from a saddle at the head of South Rice Brook, at grid reference 826577, southwest of the Columbia Icefields, and about $4 \mathrm{~km}$ WSW of Mount Alexandra and $2.2 \mathrm{~km}$ northwest of
Whiterose Mountain, at an elevation of $~ 7500$ feet, on the Rostrum Peak 1 : 50000 map sheet, at a calculated latitude of $51^{\circ} 58^{\prime} 19.20^{\prime \prime} \mathrm{N}$ and longitude $117^{\circ} 15^{\prime} 13.20^{\prime \prime} \mathrm{W}$, with an entered latitude of $51^{\circ} 58.32^{\prime} 0^{\prime} \mathrm{N}$, and longitude of $117^{\circ} 15.22^{\prime} 0{ }^{\prime \prime} \mathrm{W}$.

Conodonts associated with the illustrated sponge specimen were recovered by etching the lime mudstone matrix. The specimens are small, mostly fragmentary, and have been thermally altered to a conodont color alteration index of 4 (Epstein et al. 1977). The specimens can be ascribed to Paroistodus originalis (Sergeeva), Periodon flabellum (Lindström), and some simple cone fragments that may be referable to Propanderodus, Scolopodus, and (or) Tropodus. This fauna is representative of the North Atlantic Faunal Realm, suggestive of cool and possibly deep water. The presence of Paroistodus originalis suggests an age from middle Arenig to possibly Darriwilian (late Ibexian to early Whiterockian). A few of the elements recovered are illustrated on Fig. 2.

\section{Repository}

All illustrated specimens are assigned Geological Survey of Canada (GSC) type numbers and are housed in the National

Received 23 October 2001. Accepted 11 March 2002. Published on the NRC Research Press Web site at http://cjes.nrc.ca on 17 July 2002.

Paper handled by Associate Editor B. Chatterton.

J.K. Rigby. ${ }^{2}$ Department of Geology, Room S389 Eyring Science Center, Brigham Young University, Provo, UT 86402-4606,

U.S.A.

G.S. Nowlan. Geological Survey of Canada. 3303-33rd Street, N.W., Calgary, AB T21 2A7, Canada.

P.A. Rowlands. 2123-16A Street, Calgary, AB T2T 4K1, Canada.

${ }^{1}$ Geological Survey of Canada Contribution 2001199.

${ }^{2}$ Corresponding author (e-mail: jkr4@email.byu.edu). 
Fig. 2. Archaeoscyphia pulchra (Bassler) and associated conodonts. figs 2.1-2.4. Archaeoscyphia pulchra (Bassler), GSC 117363, from the South Rice Brook locality; scale indicated by bars shown in the figures. figs. 2.1, 2.2. Side views of an ornate, nearly complete, specimen showing the flange-like annulate growth form of the species and the basal branched root tuft system. fig. 2.3. Side view of the basal part of the sponge showing its branched root tuft attachment system and initiation of annulations on the lower part of the wall of the axial spongocoel. fig. 2.4. View from above showing the upper end of the spongocoel and its thin wall, perforated by radial canals; and the upper surface of a prominent annulation with radially aligned nodes that mark tips of skeletal trabs. figs. 2.5-2.8. Periodon flabellum (Lindström). fig. 2.5. Lateral view, Sd element, $\times 170$, GSC 117357. fig. 2.6. Lateral view, Sc element, $\times 110$; GSC 117358. fig. 2.7. Inner lateral view, ?Pb element, $\times 140$, GSC 117359. fig. 2.8. Lateral view, M element, $\times 140$, GSC 117360. figs. 2.9, 2.10. Paroistodus originalis (Sergeeva). fig. 2.9. Lateral view, drepanodontiform element, $\times 130$, GSC 117361 . fig. 2.10. Lateral view, oistodontiform element, $\times 125$, GSC 117362 . All specimens from GSC locality C-403152.

Fig. 1. Index map to the South Rice Brook locality, GSC locality C-403152, in the Canadian Rocky Mountains Main Ranges, where Archaeoscyphia pulchra (Bassler) occurs in Lower Ordovician rocks of the Outram Formation or Skoki Formation, on the Rostrum Peak, 1 : 50000 map sheet, Alberta-British Columbia.

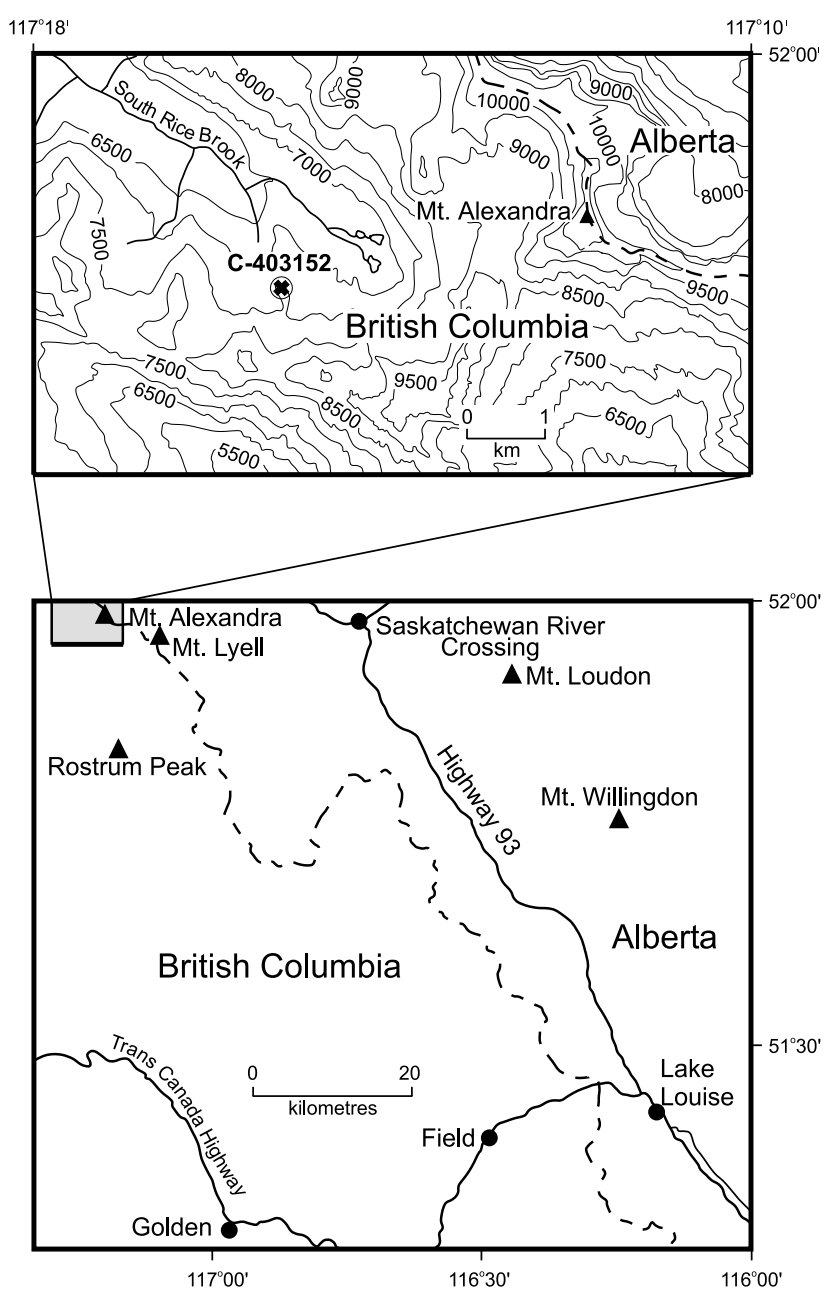

Type Collection of Invertebrate and Plant Fossils in Ottawa, Ontario.

\section{Systematic paleontology}

Class Demospongea Sollas, 1875

Order Lithistida Schmidt, 1870

Suborder Orchocladina Rauff, 1895

Family Anthaspidellidae Miller, 1889

Genus Archaeoscyphia Hinde, 1889

\section{Archaeoscyphia pulchra (Bassler, 1927)}

(Figures 2.1-2.4)

\section{Synonymy}

Nevadocoelia pulchra Bassler 1927, p. 392; Bassler 1941, pp. 95-96, pl. 20, figs. 1-4.

Archaeoscyphia annulata Cullison 1944, p. 48, pl. 24, figs. 9-12.

Archaeoscyphia pulchra (Bassler 1927). Johns 1994, pp. 44-47, pl. 4, figs. 1, 5, pl. 5, figs. 1, 3; Rigby and Desrochers 1995, pp. 18-19, figs. 6.5, 6.8.

Archaeoscyphia nana Beresi and Rigby 1993, pp. 17-20, pl. 1 , figs. 2 , 4 ; pl. 8 , figs. 3,4 .

\section{Diagnosis}

"Sponge moderate to small conico-cylindrical, annulated exterior, with deep tubular spongocoel. Annulations relatively small and sharp, with crests $7-10 \mathrm{~mm}$ apart, produced by thickening of wall and flexure of skeletal net laterally from surface of pinnation, which near gastral boundary in juvenile part but may be toward midwall in mature part of sponge. Irregular pores on exterior to $0.4 \mathrm{~mm}$ in diameter, canals may be essentially horizontal to arched upward toward gastral margin". (Rigby and Desrochers 1995, p. 18).

\section{Description}

The most complete sponge in the collection, GSC 117363, is $\sim 16 \mathrm{~cm}$ tall, from the base of the root-tuft fragments to the broken oscular margin, and is marked by upward increasingly wide annulations that extend out from the relatively simple conico-cylindrical central spongocoel region (Figs. 2.1, 2.2). That part of the skeleton expands upward from a diameter of $8-9 \mathrm{~mm}$ between the lower annulations, to $12-15 \mathrm{~mm}$ at midheight, and $\sim 25 \mathrm{~mm}$ at the upper end of the sponge. The spongocoel expands upward to a somewhat oval cross section of $14 \times 18 \mathrm{~mm}$ at the broken oscular margin, from a probable basal diameter of only 5-6 $\mathrm{mm}$, where it is probably formed of upper ends of openings of the tubular root tuft elements, below the lowest annulation. Where best seen at the incomplete oscular end, it has a wall 3.0-4.8 mm thick, and that part of the sponge has an outside diameter of $23 \times 25 \mathrm{~mm}$ between annulations.

Annulations are separated 5-8 $\mathrm{mm}$ at the spongocoel wall, with upper ones slightly more distant than lower ones, in an irregular way. Outer ends of flange-like annulations are separated 8-9 $\mathrm{mm}$ in lowest ones, to $15 \mathrm{~mm}$ in middle ones, and 13-14 $\mathrm{mm}$ in upper pronounced ones. The overall impression is of marked regularity in the inverted "conifer-appearing" sponge.

Lower annulations are minor ridges only $2-3 \mathrm{~mm}$ high 

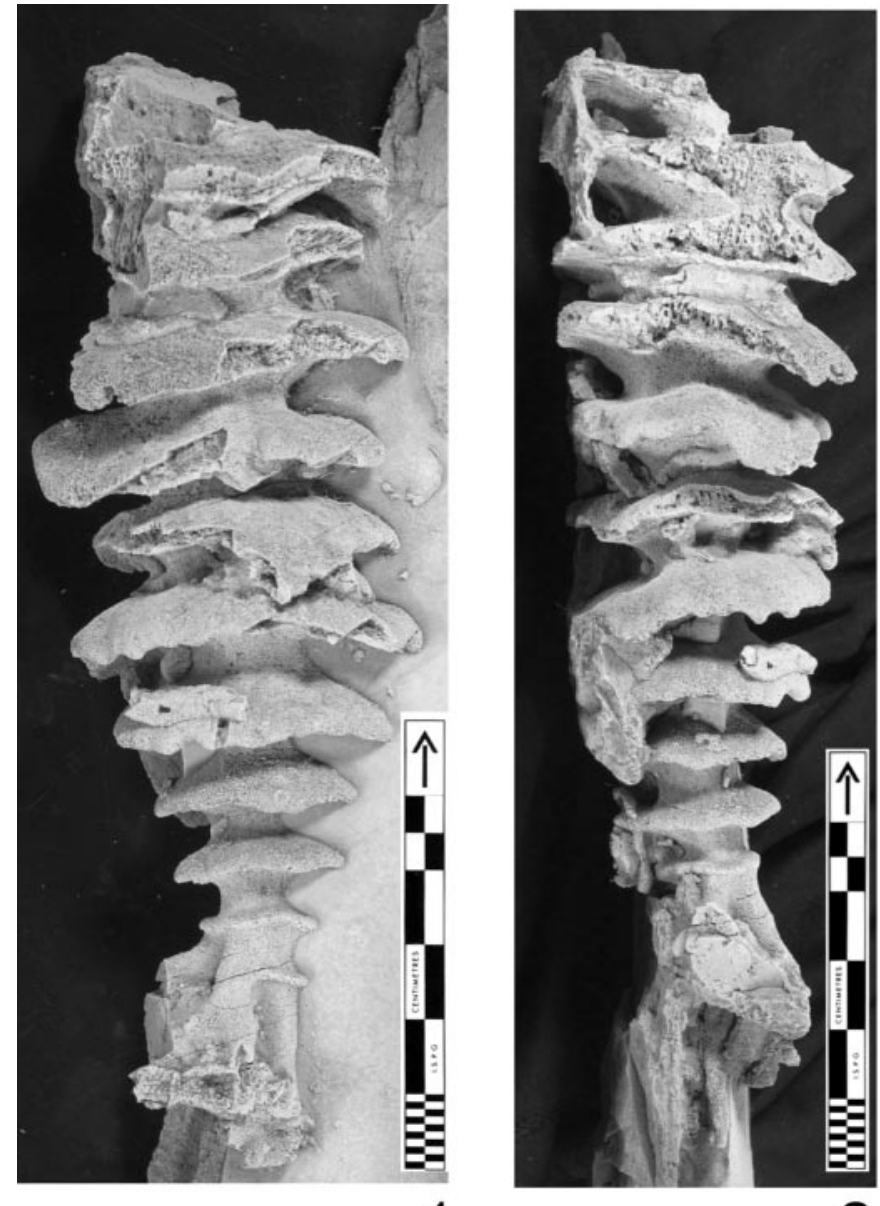

4

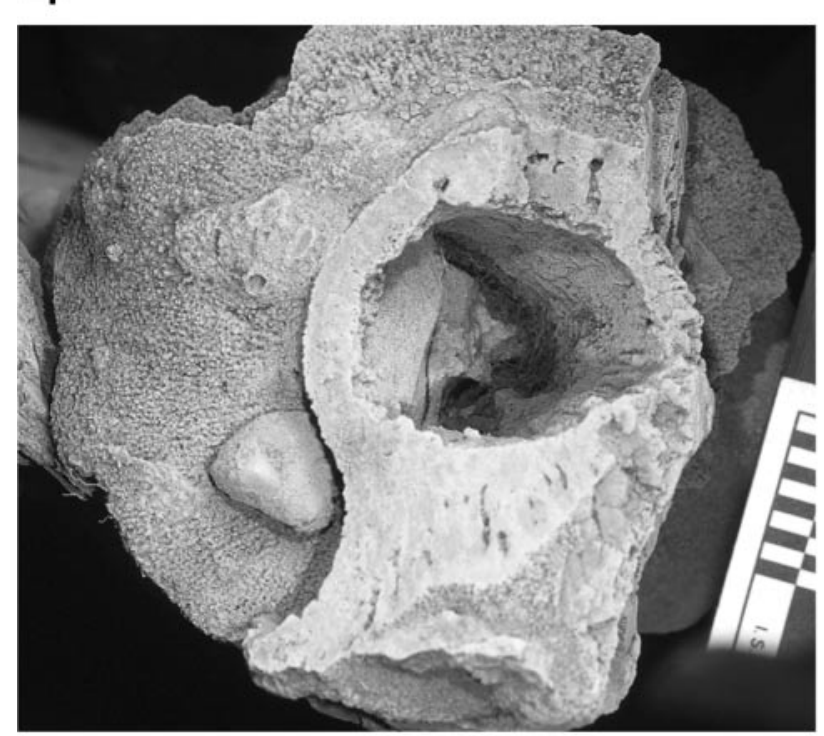

and wide, with rounded outer margins. Annulations widen upward so that at midheight they are 15 or $16 \mathrm{~mm}$ wide from the spongocoel wall margin to somewhat irregularly draped outer tips. Outer margins locally appear slightly nodose or digitate, with nodes $2-4 \mathrm{~mm}$ long and separated $\sim 1 \mathrm{~cm}$. Upper annulations are commonly incomplete, but range to $18 \mathrm{~mm}$ wide, where rounded, outer, draped margins are

2
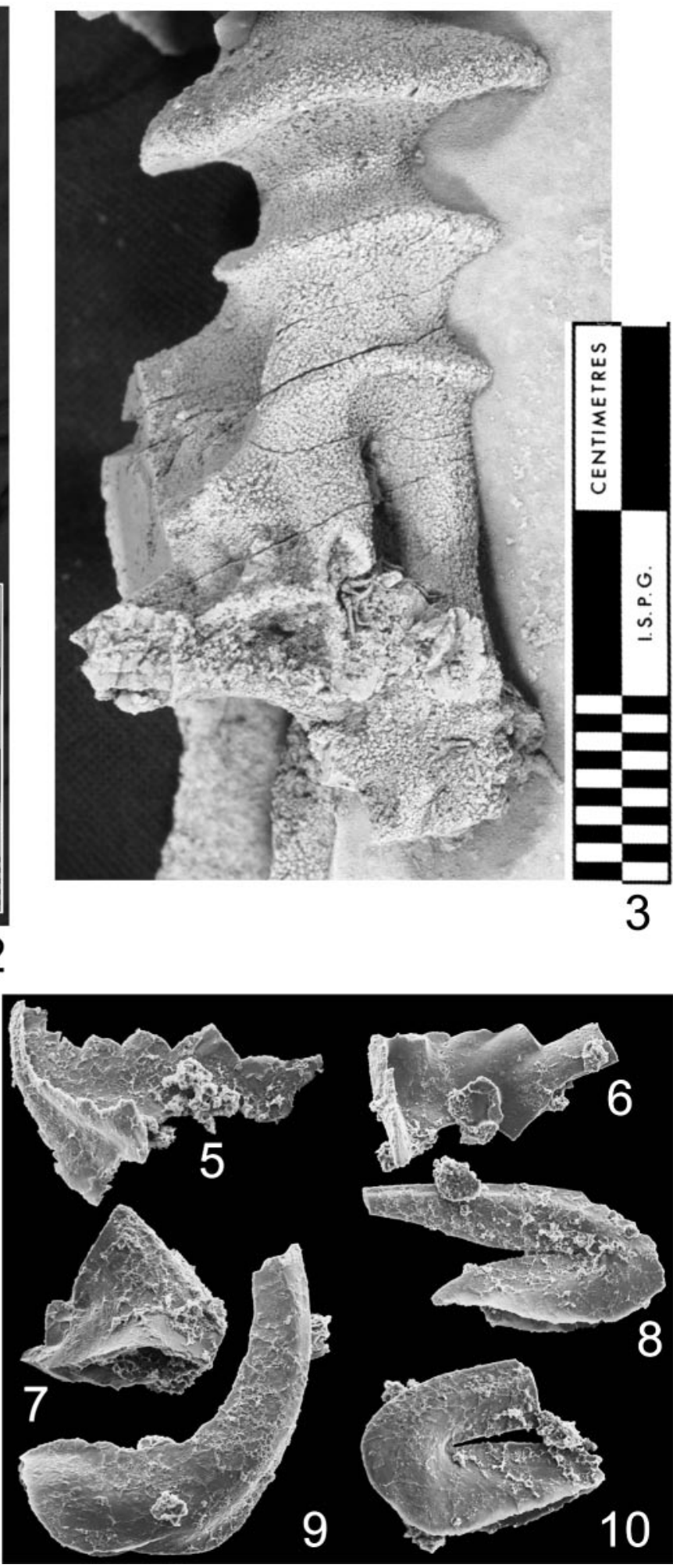

preserved. These annulations have basal or inner thicknesses that range from $2-3 \mathrm{~mm}$ in lower ones, to $4-5 \mathrm{~mm}$ thick in middle ones, and 5-6 mm thick in upper ones. All taper radially to rounded margins 1.5-2.5 mm thick. Outer parts of broad annulations drape umbrella-like in the ornate sponge.

A branched root-like system makes up the lower $35 \mathrm{~mm}$ of the specimen. These elements merge immediately below 
the lowest annulation to form the lowest cylindrical part of the skeleton. Nearly all of them have broken distal tips. The lowest root tuft is $20 \mathrm{~mm}$ long, subcylindrical, and has an oval diameter of $3 \times 4 \mathrm{~mm}$. Other tuft elements above that are commonly branched and range up to $12 \mathrm{~mm}$ long and from only $3 \mathrm{~mm}$ across to ones $4 \times 7.5 \mathrm{~mm}$, with oval cross sections where they merge immediately below the spongocoel base. These tubular-appearing, root-like elements have dense dermal layers $0.6-0.7 \mathrm{~mm}$ thick. Details of spicule structure of root tuft elements are not preserved in the silicified preservation. Dermal surfaces of tuft elements are micronodose, with moderately uniformly developed small nodes, $0.01-0.02 \mathrm{~mm}$ in diameter, that are probably tips of skeletal trabs. No coarse canals or ostia are apparent in the dermal structure.

Spicule structure of the skeleton is relatively coarsely silicified, particularly in the dermal layer, but some details are preserved in broken surfaces of a few of the upper annulations. Here the trab-based skeleton is clearly preserved, although details of the rung-like dendroclones are largely lost in the fine crystalline silicification. Trabs diverge upward and downward from a surface of pinnation in the annulations that is approximately one-quarter of the annulation thickness above the base. Trabs diverge abruptly from that surface in the lower part, to meet the lower dermal surface at high angles. Trabs diverge somewhat less abruptly in the upper part of the annulation, but still meet the upper dermal surface at high angles too. These trabs are now $0.12-0.15 \mathrm{~mm}$ in diameter, but may have been thickened during diagenesis. Dendroclones are even less well-preserved smaller structures, commonly marked as a linear series of small crystals. They also show as rod-like connections between nodose trab tips in dermal surfaces of several of the annulations and in root tuft surfaces too.

Prominent coarse exhalant canals are well defined immediately below the upper dermal surface in the interior parts of the annulations. These canals range from cylindrical openings only $0.35-0.4 \mathrm{~mm}$ in diameter, to vertically elongate, slit-like, openings $0.4 \mathrm{~mm}$ wide and up to $1.2 \mathrm{~mm}$ high. These canals are generally spaced $1.2-1.4 \mathrm{~mm}$ apart, and separated by two or three trabs.

Smaller inhalant canals are less well defined but do occur as ostia $0.010-0.15 \mathrm{~mm}$ in diameter in the dermal layer, and also as openings $0.20-0.25 \mathrm{~mm}$ in diameter between trabs in the interior of the annulations.

A second small piece of the species, GSC 117364, shows the same flange-like skeletal structure around a central open spongocoel. It is $58 \mathrm{~mm}$ tall and incomplete at both the base and oscular ends. It has moderately coarse annulations, with diameters of up to $31 \mathrm{~mm}$, that are 5-6 $\mathrm{mm}$ thick and up to $12 \mathrm{~mm}$ wide. They are spaced $9-12 \mathrm{~mm}$ apart along the axial spongocoel. The latter is $5 \times 8 \mathrm{~mm}$ across in the lower end and $8 \times 13 \mathrm{~mm}$ across the oval opening in the upper end of the fragment. The wall surrounding the spongocoel is 2-3 mm thick. This fragment would appear to be from the lower part of a sponge like the larger, more complete fragment described earlier in the text, but certainly belongs to the same species.

\section{Remarks}

The species was erected for a somewhat larger sponge from the Lower Ordovician Pogonip beds of the Toquima Range of Nevada (Bassler 1941, p. 95, pl. 20, figs. 1-4), but the growth form with prominent annulations that occur at regular intervals of $\sim 1 \mathrm{~cm}$ along the tubular spongocoel seems the same and is considered diagnostic. The type specimen from Nevada is $7 \mathrm{~cm}$ in greatest diameter in the fragment only $11 \mathrm{~cm}$ tall, and it may have come, initially, from a taller specimen than those described here.

Specimens of the species from the Mingan Islands, described by Rigby and Desrochers (1995, p. 18-19, figs. 6.5, 5.8) from the basal Grande Pointe Member of the Mingan Formation, are of the same general size as the present sponges, but with somewhat less prominent annulations.

As noted by Rigby and Desrochers (1995, p. 19), Johns (1994, p. 46) placed Archaeoscyphia annulata Cullison 1944 into synonymy with Archaeoscyphia pulchra because he could see no differences in the species, although the skeletal structure of the former is not well known because of intense silicification. The exterior form seems sufficiently diagnostic, however.

Archaeoscyphia nana Beresi and Rigby 1993 is a small sponge with the same general prominent annulate growth form and dimensions as those recognized here for Archaeoscyphia pulchra (Bassler). The species was initially differentiated from Archaeoscyphia pulchra based upon distinct differences in size. However, the upward increase in size and general dimensions seen in the larger Canadian specimen described here would suggest that $A$. nana Beresi and Rigby should also be placed into synonymy with A. pulchra.

\section{Acknowledgments}

Brian Rutley (Geological Survey of Canada) took the digital images of the sponge fossils and Jenny Wong (Geological Survey of Canada) did the digital scanning electron microscopy of the conodonts. Vytas Barsauskas of Ridgewood, New Jersey, and Roger Wallis of Toronto, Ontario, collected additional sponge specimens from this locality. Brian Norford provided a helpful review of an early version of the manuscript. We also appreciate constructive reviews of the submitted manuscript by John W. Pickett and Marcelo G. Carrera, and similar assistance by the Associate Editor.

\section{References}

Bassler, R.S. 1927. A new Early Ordovician sponge fauna. Washington Academy of Sciences Journal, 17: 390-394.

Bassler, R.W. 1941. The Nevada Early Ordovician (Pogonip) sponge fauna. U. S. National Museum Proceedings, 91: 91-102.

Beresi, M.S., and Rigby, J.K. 1993. The Lower Ordovician sponges of San Juan, Argentina. Brigham Young University Geology Studies, 39: 1-63.

Cullison, J.S. 1944. The stratigraphy of some Lower Ordovician formations from the Ozark Uplift. Bulletin of the University of Missouri School of Mines and Metallurgy, Technical Series, 15(2): 1-112.

Epstein, A.G., Epstein, J.B., and Harris, L.D. 1977. Conodont color alteration-an index to organic metamorphism. U. S. Geological Survey Professional Paper 995.

Hinde, G.J. 1889. On Archaeocyathus Billings, and on other genera, allied to or associated with it, from the Cambrian strata of North 
America, Spain, Sardinia, and Scotland. Geological Society of London Quarterly Journal, 45: 125-148.

Johns, R.A. 1994. Ordovician lithistid sponges of the Great Basin. Nevada Bureau of Mines and Geology Open-file Report, 1994-1.

Miller, S.A. 1889. Class Porifera. In North American Geology and Paleontology. Western Methodist Book Concern, Cincinnati, Ohio. (Published by the author), pp. 152-167. [Includes some genera that were first published here, from page proofs of Ulrich and Everett (1890), so those genera should be cited as Ulrich and Everett, in Miller]

Rauff, H. 1895. Palaeospongiologie. Palaeontographica, 43: 223-272.
Rigby, J. K., and Desrochers, A. 1995. Lower and Middle Ordovician lithistid demosponges from the Mingan Islands, Gulf of St. Lawrence, Quebec, Canada. Paleontological Society Memoir 41 (Journal of Paleontology, 69(4): supplement).

Schmidt, O. 1870. Grundzüge einer Spongien-fauna des atlantischen Gebietes. Wilhelm Engelmann, Leipzig, Germany.

Sollas, W.J. 1875. Sponges. In Encyclopaedia Britannica, 9th ed. London, p. 451.

Ulrich, E.O., and Everett, O. 1890. Lower Silurian sponges. Geological Survey Bulletin 8, Paleontology of Illinois, Part 2, Section 4, pp. 242-253. 
Copyright of Canadian Journal of Earth Sciences is the property of NRC Research Press and its content may not be copied or emailed to multiple sites or posted to a listserv without the copyright holder's express written permission. However, users may print, download, or email articles for individual use. 